\title{
Angiotensin-I converting enzyme (ACE-I) inhibitory and antiproliferative potential of chickpea seed protein hydrolysate
}

Neha Gupta and Sameer Suresh Bhagyawant*

School of Studies in Biotechnology, Jiwaji University, Gwalior, 474011, India.

Received: 2/19/2018; Revised: 2/21/2018; Accepted: 2/27/2018

\begin{abstract}
Chickpea seeds are the preferred source of proteins possessing health care functions in countries across the world. In the present investigation, the chickpea seed protein subjected to enzymatic hydrolysis produced bioactive peptides that were able to inhibit the angiotensin converting enzyme (ACE) and cytotoxic effect. Experimental screening was to test the efficacy of hydrolytic enzymes in chickpea seed for production of bioactive peptides was therefore carried out. The optimum hydrolysis times for each protein hydrolysate prepared by alcalase which inhibited ACE-I with $\mathrm{IC}_{50}$ value of $52.22 \mu \mathrm{g} / \mathrm{ml}$. The protein hydrolysate was further subjected to antiproliferative evaluation for breast cancer cell lines MCF-7 and MDA-MB-231 and the IC 50 was observed $0.71 \mathrm{mg} / \mathrm{ml}$ and $0.78 \mathrm{mg} / \mathrm{ml}$ respectively. Study indicated the potential of chickpea proteins as a source of ACE-inhibitory and antiproliferative potential to foresee the application of chickpea proteins into functional foods.
\end{abstract}

Key words: ACE-I inhibitory activity, Chickpea seeds, Hydrolysis.

\section{Introduction}

Food legumes are known to produce functional proteins and ascribed prevention of many health disorders. The fatalities of CVDs presently accounts for 30\% human mortality (Erdmann et al., 2008). The bioactive proteins/peptides provides functional principles to various disease lowering concerns that include blood pressure lowering, cardiovascular diseases and anti-inflammatory features (Wu et al., 2006). Therefore, identification and characterization of such bioactive peptides are being explored. Recently, the bioactive peptides like angiotensin Iconverting enzyme (ACE) inhibitory peptides derived from plant sources have attracted scientific attention because of their roles in health care (Hua et al., 2011).

ACE, a dipeptidyl carboxpeptidase (EC 3.4.15.1), is involved in peripheral hypertension as well as overall cardiovascular functioning. It catalyses the conversion of the inactive decapeptide angiotensin-I into the potent vaso-constricting octapeptide angiotensin-II and also inactivates the potent vasodilator, bradykinin (Wu et al., 2006). The inhibition of ACE may result in hypotension. Many potent synthetic ACE inhibitors such as captopril, enalapril, lisinopril and ramipril are widely used in the clinical treatment of hypertension related cardiac failures. These synthetic ACE inhibitors however have been reported to lead adverse side effects such as cough, taste disturbances, rashes and angioedema (Erdmann et al., 2008). Therefore, the quest for natural plant products acting as a chief component of the functional foods for the management of hypertension is underway (Wang et al., 2016).

Plant derived ACE inhibitory peptides as generated from enzymatic hydrolysates, demonstrate antihypertensive activity and antiproliferative effect under in vivo and in vitro systems (Gupta et al., 2018; Wang et al., 2016; Li et al., 2006). Jakubczyk and Baraniak, (2013) have evaluated lentil protein digested peptides for ACE-I inhibitory potential. Wang et al., (2016) have isolated and purified ACE inhibitory peptide of $929 \mathrm{Da}$ molecular weight which had amino acid sequence of Tyr-Val-ProHis-Trp-Asp-Leu.

Chickpea (Cicer arietinum) seed protein contains essential amino acid needed by the human body, showing a nutrition-based health care functions. The major storage proteins of chickpea are globulins $(56.0 \%)$, glutelins $(18.1 \%)$, albumins $(12.0 \%)$ and prolamin $(2.8 \%)$. The objective of the present work was to evaluate chickpea protein hydrolysates using gastrointestinal enzymes, like alcalase possessing ACE inhibitory activity and antiproliferatve effect in vitro.

\section{Materials and Methods}

\section{Seed Material}

The mature and dry seed material was obtained from Indian Institute of Pulses Research (IIPR), Kanpur (U.P.), India under MTA understanding.

\section{*Corresponding Author:}

Dr. Sameer S. Bhagyawant,

Molecular Biology Lab,

SOS in Biotechnology,

Jiwaji University, Gwalior (474011), India.

E-mail: sameerbhagyawant@.gmail.com, ng.biotech.ng@gmail.com 


\section{Protein concentrates preparation}

Ground flour of chickpea seeds was defatted by hexane $(1: 10 \mathrm{w} / \mathrm{v})$ employing constant stirring for 8 $\mathrm{h}$ at $4^{\circ} \mathrm{C}$. For protein extraction, isoelectric precipitation method was carried out. Briefly, protein extraction using flour to solvent ratio of $1: 10(\mathrm{w} / \mathrm{v})$ was performed in distilled water at $\mathrm{pH}$ 8.0. This flour suspension ( $25 \mathrm{~g}$ flour in $250 \mathrm{~mL}$ of water at $\mathrm{pH} 8$ ) was stirred at $4{ }^{\circ} \mathrm{C}$ in magnetic stirrer for $1 \mathrm{~h}$ and subsequently centrifuged at $10,000 \times \mathrm{g}$ for $15 \mathrm{~min}$. The supernatant so obtained was vacuum filtered using $100-160 \mathrm{~m}$ pore size filter funnel. Finally filtrates were freeze-dried and stored at $-20{ }^{\circ} \mathrm{C}$ under vacuum in plastic bags.

\section{Enzymatic hydrolysis}

Treatments with alcalase protein concentrate hydrolysis was done using the method of Pedroche et al., (2002). Hydrolysis reaction was performed for $120 \mathrm{~min}$ by adding $2 \%(\mathrm{w} / \mathrm{v})$ alcalase $(\mathrm{pH})$ in the final volume at $50{ }^{\circ} \mathrm{C}$ temperature and $\mathrm{pH}$ was kept constant during hydrolysis. The reaction was stopped by heating to $85^{\circ} \mathrm{C}$ for $15 \mathrm{~min}$. Protein hydrolysates were clarified filtering through $0.45 \mathrm{~nm}$ filters to remove the insoluble matter. The filtrates maintained at $70{ }^{\circ} \mathrm{C}$ were lyophilised and named as alcalase-generated chickpea protein hydrolysate.

\section{Degree of hydrolysis}

The protocol of De Castro and Sato, (2014) was followed to determine DH with slight modification. Briefly, to the different time interval withdrawn hydrolysates $(0.5 \mathrm{ml}), 12 \%$ trichloroacetic acid $(0.5$ $\mathrm{ml}$ ) was added and centrifuged at 10,000 x g for 20 min. Using Lowry et al., (1951) method, the protein content was determined and $\mathrm{DH}$ was calculated as the ratio of TCA-soluble protein to total protein in the hydrolysate.

\section{Extraction of ACE from rabbit lungs:}

Rabbit lungs as donated by the pharmacology laboratory of Defence Research \& Development Establishment (DRDE), Gwalior Madhya Pradesh state of India, was used to obtain an angiotensin converting enzyme (ACE) source following the method of Cushman and Cheung, (1971). Briefly, lung sample was ground in liquid nitrogen and homogenized in $10 \mathrm{mM}$ potassium phosphate buffer ( $\mathrm{pH}$ 8.3), containing $100 \mu \mathrm{m}$ pepstatin and $0.1 \mathrm{mM}$ PMSF. The homogenate was centrifuged at $5000 \mathrm{x} \mathrm{g}$ for $10 \mathrm{~min}$ and resulting supernatant was dialysed for $2 \mathrm{~h}$ against 20 volumes of the same buffer in cold. This dialysed supernatant was used as a source of angiotensin converting enzyme. To verify the absence of undesirable proteases such as carboxypeptidase in ACE extracts, the kinetics of HHL hydrolysis by ACE was followed in the presence or absence of captopril, a potent ACE inhibitor. The hydrolysis is due to ACE only and not to other proteases was confirmed by the following figure 1 .

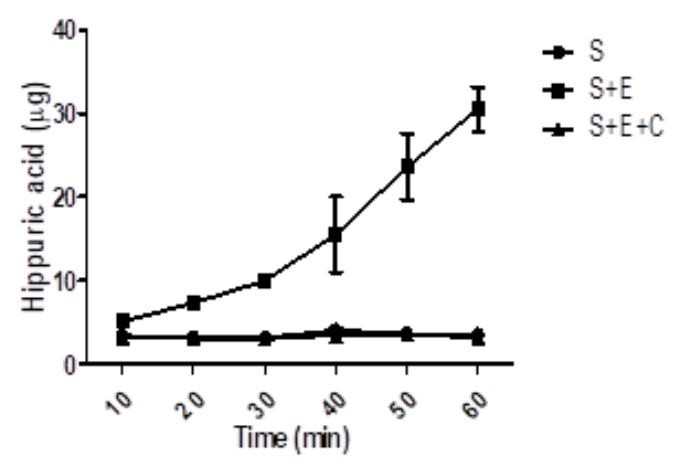

Figure 1. Kinetics of hydrolysis of substrate HHL (S) by ACE (E) in presence or absence of captopril (C).

\section{Spectrophotometric assay for ACE activity:}

Determination of the ACE inhibitory activities of the digests was performed according to the method of Cushman and Cheung, (1971) with minor modifications. One hundred microlitres of CP and ACPH were added to $500 \mu \mathrm{l}$ mixture containing 100 $\mu \mathrm{l}$ of $100 \mathrm{mM}$ phosphate buffer $(\mathrm{pH} 8.3), 100 \mu \mathrm{l}$ of $300 \mathrm{mM} \mathrm{NaCl}, 200 \mu \mathrm{l}$ of $5 \mathrm{mM}$ Hippuryl-LHistidyl-L-Leucine (HHL) and $100 \mu \mathrm{l}$ of ACE isolated from rabbit lungs. The mixture was incubated at $37^{\circ} \mathrm{C}$ for $30 \mathrm{~min}$ on incubator shaker and the reaction was stopped by adding $500 \mu \mathrm{l}$ of 1 $\mathrm{N} \mathrm{HCl}$. The mixture was added with $3.0 \mathrm{ml}$ of ethyl acetate and mixed through vortex for $15 \mathrm{~s}$. Ethyl acetate layer was obtained and the solvent was allowed to evaporate. The residue was redissolved in $1.0 \mathrm{ml}$ of distilled water and the absorbance of the resulting solution was recorded at $228 \mathrm{~nm}$. Blank was prepared without addition of peptide sample. Pulverized captopril served as positive control. ACE inhibitory activities were expressed as inhibitory activity $(\mathrm{U})$, percent inhibition and $\mathrm{IC}_{50}$ values. All values are means of three experimental trials.

Sulphorhodamine B (SRB) assay for cytotoxicity assessment

The SRB assay was performed as reported earlier by Skehan et al., (1990). Briefly, the cells were fixed with $10 \%$ chilled trichloroacetic acid (TCA) for $1 \mathrm{hr}$ at $4^{\circ} \mathrm{C}$. The supernatant was aspirated and plates were washed thrice with chilled deionized water and subsequently air-dried. $100 \mu \mathrm{L}$ of $0.4 \%$ (w/v) SRB in $1 \%$ acetic acid was added to each well and incubated for 30 minutes at room temperature. Unbound SRB was removed by 3 washes with $1 \%$ acetic acid till the plates get air-dried. $200 \mu \mathrm{L}$ of unbuffered $10 \mathrm{mM}$ tris base, $\mathrm{pH}$ (10.5) was added for extracting the bound stain. The absorbance was read at $560 \mathrm{~nm}$ in microplate reader (Bio-Rad, USA). The $\%$ cell inhibition was calculated using the following formula:

Cell proliferation inhibition $(\%)=$

$$
\text { [1- } \left.\left(\mathrm{A}_{\mathrm{s}} / \mathrm{A}_{\mathrm{c}}\right)\right] \times 100
$$

Where: As - absorbance of sample; Ac - absorbance of control 


\section{Results and Discussion}

Being a promising source of protein chickpea seed demonstrated ACE-I inhibitory property at different levels. The defatted chickpea seeds flour was used as a source for the preparation of chickpea protein $(\mathrm{CP})$ and tested the total protein contents in the seeds of all chickpea accessions before hydrolysis. It was found that total protein content was ranged $20-24.2 \%$ in chickpea. In order to obtain extensive hydrolysates with $\mathrm{DH}$ greater than $50 \%$, it was necessary to use more than one protease. In general, one enzyme can't achieve high $\mathrm{DH}$ in reasonable period of time. The inhibitory activity of hydrolysates varied from $56.2 \pm 2.7$ to 44 $\pm 5.0 \%$. The $2 \mathrm{hr}$ incubation was a benchmark for chickpea protein hydrolysate, generating active peptides. The activities of protein hydrolysates depend on the protein substrate, proteolytic enzyme, time and temperature of hydrolysis as well as amino acid composition and sequence as per literature evidances (Daskaya et al., 2017).

\section{Enzymatic hydrolysis}

Depending on the use of enzyme system at subsequent reaction time, the degree of hydrolysis differed. For example, alcalase at $2 \mathrm{hr}$ reaction time catalyzed highest degree of hydrolysis in desi, kabuli and wild type chickpea seeds. Alcalase is an alkaline protease that produced chickpea protein hydrolysates with better functional characteristics than the original protein. Alcalase is known to generate bioactive peptides with ACE-I inhibitory activity consequently been used as a purified fraction as described in earlier reports. The bacterial origin Bacillus licheniformis, alcalase exhibits the subtilisin Carlsberg serine group in its active site, which has endopeptidase activity. To the extreme C-terminal end, this enzyme hydrolyzes peptides with a wide specificity and releases hydrophobic amino acids such as Phe, Tyr, Trp, Leu, Ile, Val and Met (Markland et al., 1971). It is obvious that potent ACE-inhibitory peptides have a hydrophobic or aromatic amino acid residues in each of the three Cterminal positions are therefore undergo catalysis (Hong et al., 2005). For the above reasons, it is quite probable that the hydrophobic amino acid content of the studied legume seeds is similar to Phaseolus radiatus L. (39.75\%), meaning chickpea seeds studied here are appropriate substrates for producing peptides with ACE-I inhibitory action using alcalase enzyme (Hong et al., 2005).

\section{ACE-I Inhibitory activity}

The crude protein hydrolysate of chickpea seeds prepared by alcalase enzyme digestion were measured for ACE-I inhibitory activity. The $\mathrm{IC}_{50}$ values of alcalase hydrolysate was found significant $(\mathrm{P}<0.05)$. The hydrolysate prepared by alcalase at 2 $\mathrm{h}$ revealed highest ACE-I inhibitory activity (lowest $\left.\mathrm{IC}_{50}\right)$ with $\mathrm{IC}_{50}$ value $52.22 \mu \mathrm{g} / \mathrm{ml}$, when $1 \mathrm{mg}$ protein was used. The most potent ACE-I inhibitory activity of protein hydrolysate was compared to the inhibitory activity of the standard antihypertension drug captopril.

As previously indicated, differences in ACE inhibitory activity reported from earlier studies may attribute to sample composition as well as differences in the peptide composition of the hydrolysates. In addition, proteolytic enzymes used in the digestion of parent proteins and the experimental conditions used in processing play a significant role. Previous studies corroborate the influence of enzymatic digestion on generation of ACE inhibitory activity obtained from food proteins (Yust et al., 2003; Vermeirssen et al., 2003). The parameters of the hydrolytic process such as $\mathrm{pH}$, temperature, enzyme-to-substrate ratio and hydrolysis time, also influence the release of peptides from food proteins that show ACE-I inhibitory reactions (Vermeirssen et al., 2003). As already mentioned in the introduction, limited data is available on ACE-inhibiitory activity in the seeds of chickpea. It is noticed that alcalase is more efficient endopeptidase than papain and pancreatin cleaving bonds of hydrophobic amino acids pool of chickpea seeds (Medina-Godoy et al., 2012). Boschin et al., (2014) worked on ACE-I inhibitory activity of enzymatic protein hydrolysates from other legumes that included pea, lentils, bean and chickpea also. Apart from this, in-vitro ACE-I inhibition, in-vivo antihypertensive activities of bioactive peptides derived from various plant sources are available in literature domain (Yust et al., 2003; Vermeirssen et al., 2003). Most of these studies revealed that ACE-inhibitory peptides are of non-competitive nature and exert antihypertensive ability through protecting vascular endothelial cells from reactive oxygen species mediated damage.

Antiproliferative effects of chickpea protein in human breast cancer cells

The morphological changes of different concentrations of extracts $(0.2 \mathrm{mg}-1.0 \mathrm{mg})$ showed dose-dependent antiproliferative activities against these cell lines. After $48 \mathrm{~h}$ treatment the $\mathrm{IC}_{50}$ of alcalase extracts was $0.71 \mathrm{mg} / \mathrm{ml}$ in MCF-7 cells similarly the $\mathrm{IC}_{50}$ of $0.78 \mathrm{mg} / \mathrm{ml}$ in MDA-MB-231 compared to chickpea protein with $\mathrm{IC}_{50}$ of 0.89 $\mathrm{mg} / \mathrm{ml} \quad$ (Figure 2). Interestingly chickpea hydrolysate showed significant dose dependent antiproliferative effect against both cancer cells, compared to chickpea protein. The results on IC50 values of chickpea hydrolysate for the cancer cells compared to the chickpea protein, suggests that chickpea hydrolysate may possibly have potential as an anti-cancer agent. However further studies are required to prove the safety and efficacy of chickpea hydrolysate as a potential chemopreventive agent in clinical practice. 


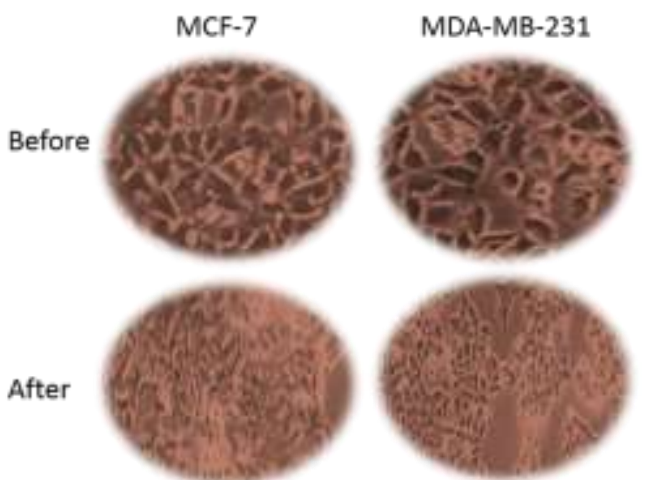

Figure 2. Morphological changes of breast cancer cell line MCF-7 and MDA-MB-231 treated with chickpea protein hydrolysate

\section{Conclusion}

This study shows that defatted chickpea seeds can be regarded as a value-added by-product of the food industry. Hydrolysis by proteolytic enzyme like, alcalase produced high ACE-inhibitory activity and antiproliferative effect. According to our results, chickpea seed protein is a promising protein source for the production of ACE-inhibitory peptides which might be utilized to develop foods for hypertension prevention and chemopreventive agent. Further research is still necessary to elucidate the possible in-vivo effects of chickpea seed peptide fractions.

\section{References}

1. Boschin G, Scigliuolo GM, Resta D, Arnoldi A, ACE-inhibitory activity of enzymatic protein hydrolysates from lupin and other legumes, Food Chemistry, 2014, 145, 34-40.

2. Cushman DW, Cheung HS, Spectrophotometric assay and properties of the angiotensin-converting enzyme of rabbit lung, Biochemistry Pharmacology, 1971, 20, 16371648.

3. Daskaya DC, Yucetepe A, Karbancioglu GF, Daskaya H, Ozcelik B, Angiotensin-IConverting Enzyme (ACE)-Inhibitory Peptides from Plants, Nutrients, 2017, 23, 9(4).

4. De Castro RJS, Sato HH, Antioxidant activities and functional properties of soy protein isolate hydrolysates obtained using microbial proteases, International Journal of Food Science \& Technology, 2014, 49, 317-328.

5. Erdmann K, Cheung BWY, Schroder H, The possible roles of food-derived bioactive peptides in reducing the risk of cardiovascular disease, Journal of Nutritional Biochemistry, 2008, 19, 643-654.
6. Gupta N, Srivastava N, Bhagyawant, SS, Vicilin-A major storage protein of mungbean exhibits antioxidative potential, antiproliferative effects and ACE inhibitory activity. PLoS ONE, 2018, 13(2), e0191265

7. Hong LG, Wei LG, Liu H, Hui SY, Mung-bean protein hydrolysates obtained with alcalase exhibit angiotensin I-converting enzyme inhibitory activity, Food Science and Technology, Inter 2005, 11, 281-287.

8. Hua ZY, Jun GJ, Hua LZ, Jing T, Research progress of ACE inhibitory peptide. Cereals Oils, 2011, 25, 44-46.

9. Jakubczyk A, Baraniak B, Activities and sequences of the angiotensin I-converting enzyme (ACE) inhibitory peptides obtained from the digested lentil (Lens culinaris) globulins Inter, Journal of Food Science and Technology, 2013, 48, 2363-2369.

10. Li GH, Shi YH, Liu H, Le GW, Antihypertensive effect of alcalase generated mung bean protein hydrolysates in spontaneously hypertensive rats, European Food Research Technology, 2006, 222, 733736.

11. Lowry OH, Rosebrough NJ, Farr AL, Randall RJ, Protein measurement with the folin phenol reagent, The Journal of Biochemistry, 1951, 193, 265-275.

12. Markland FS, Smith EL, Subtilisins: primary structure, chemical and physical properties. In P. D. Boyer (Ed.), The enzyme (1st ed.). New York: Academic Press, 1971, 561-608.

13. Medina-Godoy S, Ambriz-Pérez DL, FuentesGutiérrez CI, Germán-Báez LJ, GutiérrezDorado R, Reyes-Moreno C, Valdez-Ortiz A, Angiotensin-converting enzyme inhibitory and antioxidative activities and functional characterization of protein hydrolysates of hard-to-cook chickpeas, Journal of Science, Food and Agriculture, 2012, 92, 1974-81.

14. Pedroche J, Yust MM, Giro'n-Calle J, Alaiz M, Milla 'n F, Vioque J, Utilisation of chickpea protein isolates for production of peptides with angiotensin I-converting enzyme (ACE)inhibitory activity, Journal of Science, Food and Agriculture, 2002, 82, 960-965.

15. Skehan $\mathrm{P}$, et al., New colorimetric cytotoxicity assay for anticancer-drug screening. J. of National Cancer Institute, 1990, 82, 1107-1112. 
16. Vermeirssen V, Van Camp J, Devos L, Verstraete W, Release of angiotensin I converting enzyme (ACE) inhibitory activity during in vitro gastrointestinal digestion: from batch experiment to semi continuous model, Journal of Agriculture and Food Chemistry, 2003, 51, 5680-5687.

17. Wang FJ, Yin XY, Regenstein JM, Wang JZ, Separation and purification of angiotensin-Iconverting enzyme (ACE) inhibitory peptides from walnuts (Juglans regia L.) meal. European Food Research Technology, 2016, 242, 911 918.

18. Wu WL, Wu GJ, Liang DS, Yang F, The physiological function and research progress of
angiotensin-I-converting enzyme inhibitory peptides. Journal of Food Science and Technology, 2006, 22, 251-254.

19. Yust MM, Pedroche J, Girón-Calle J, Alaiz M, Millán F, Vioque J, Production of ace inhibitory peptides by digestion of chickpea legumin with alcalase, Food Chemistry, 2003, $81,363-369$

\section{Cite this article as:}

Neha Gupta and Sameer Suresh Bhagyawant. Angiotensin-I converting enzyme (ACE-I) inhibitory and antihypertensive potential of chickpea seed protein hydrolysate. Annals of Plant Sciences 7.3 (2018) pp. 2149. 2153.

do7 http://dx.doi.org/10.21746/aps.2018.7.3.10

Source of support: Nil 